Chandra, R. K. (1973). Archives of Disease in Childhood, 48, 157. Chandra, R. K. (1974). Medicine et Chirurgie Digestives, 3, 63. Chandra, R. K. (1975). Indian Pediatrics. In press. Cherry, J. D., et al. (1971). Fournal of Pediatrics, 79, 937. Danes, B. S., and Bearn, A. G. (1968). Lancet, 1, 1061. Danes, B. S., and Bearn, A. G. (1969). Fournal of Experimental Medicine, 129,775 .

Danks, D. M., Allan, J., and Anderson, C. M. (1965). Annals of Human Genetics, 28, 323.

Gitlin, D., and Boesman, M. (1966). Fournal of Clinical Investigation, 45, 1826.
Leek, A. E., et al. (1973). Lancet, 2, 385.

Lockhart, L. H., Bowman, B. H., and Peters, D. (1968). Southern Medical Fournal, 61, 1356.

Masopust, J., et al. (1971). International fournal of Cancer, 3, 364

Masopust, J., et al. (1971). International four

Nayak, N. C., et al. (1972). Lancet, 1, 86.
Rennert, O. M., et al. (1972). Clinical Pediatrics, 11, 351.

Ruoslahti, E., and Seppala, M. (1971). International fournal of Cancer, 8 374.

Spock, A., et al. (1967). Pediatric Research, 1, 173.

Waldman, T. A., and McIntire, K. R. (1972). Lancet, 2, 1112.

Wright, S. W., and Morton, N. E. (1968). Hawaii Medical fournal, 27, 229.

\title{
Highly Selective Vagotomy for Duodenal Ulcer : Do Hypersecretors Need Antrectomy?
}

\author{
D. JOHNSTON, I. R. PICKFORD, B. E. WALKER, J. C. GOLIGHER
}

British Medical fournal, 1975, 1, 716-718

\section{Summary}

Two to five years after highly selective vagotomy (H.S.V.) for duodenal ulcer the results were similar in patients with high preoperative maximal acid outputs and those with lower acid outputs. Pain of ulcer type was experienced at some time by $6 \%$ of patients from each group, but it was mild and transient in some. No patients had recurrent ulceration at endoscopy or laparotomy, while incidence of individual symptoms was about equal in the two groups.

Hence H.S.V. is adequate surgical treatment for patients with both duodenal ulceration and high levels of acid secretion. Antrectomy in such patients is not necessary provided that the incidence of incomplete vagotomy can be kept low.

\section{Introduction}

Some authorities customarily add an antrectomy to vagotomy when operating for duodenal ulcer (Herrington, 1969; Smithwick et al., 1961). Others are more selective and base their choice of operation on the magnitude of preoperative acid output (Bruce et al., 1959; Small et al., 1967). Vagotomy with antrectomy for patients who have a very high maximal acid output before operation and vagotomy with a drainage procedure for the remainder has been strongly advocated by Kronborg (1972, 1974) and Robbs et al. (1973). Antrectomy with vagotomy undoubtedly diminishes the risk of recurrent ulceration, but operative mortality is increased; side effects occur more often than after the newer types of vagotomy (Amdrup et al., 1974); and long-term weight loss is greater (Goligher et al., 1968).

Our purpose was to find out whether highly selective vagotomy (H.S.V.) provided adequate surgical treatment for all patients with duodenal ulcer or whether antrectomy was also needed in the hypersecretors. Since 1969 we have treated all patients having surgery for duodenal ulcer, irrespective of their preoperative maximal acid output by H.S.V. without drainage (Johnston and Wilkinson, 1969, 1970; Amdrup et al., 1974). \footnotetext{
University Department of Surgery, General Infirmary, Leeds LS1
3EX.

D. JOHNSTON, M.D., F.R.C.s., Reader in Surgery

I. R. PICKFORD, Medical Student

J. C. GOLIGHER, ch.M., F.R.C.S., Professor of Surgery University Department of Medicine, St. James's Hospital, Leeds
LS9 7TF

B. E. WALKER, M.D., M.R.C.P., Lecturer in Medicine
}

This is an even more conservative operation than truncal or selective vagotomy with drainage because it leaves the gastric antrum vagally innervated and the pyloric sphincter intact. Patients were reviewed at a gastric follow-up clinic at yearly intervals to find out whether those who had had hypersecretion of acid before operation had worse clinical results or a higher incidence of recurrent ulceration than patients whose maximal acid output had been normal.

\begin{abstract}
Methods
Patients.-As the women's results did not differ from the men's they were considered together. Only patients who had undergone elective H.S.V. in the treatment of chronic duodenal ulcer two to six years previously were included. The maximal acid output in response to pentagastrin had been measured in each patient both before operation and five to 10 days after vagotomy. Each patient had also undergone an insulin test five to 10 days after operation. Patients were followed up at yearly intervals at a gastric follow-up clinic. They were interviewed by a panel of doctors who did not learn the patient's diagnosis or the nature of the operation until they had assessed the answers to standard questions and made their collective verdict according to a modified Visick system of grading (Goligher et al., 1968).

Criteria of Hypersecretion.-Peak acid output as assessed by the pentagastrin test (P.A.O.) was calculated as the highest of four consecutive five-minute readings multiplied by three and expressed as $\mathrm{mmol}(\mathrm{mEq}) \mathrm{HCl} /$ hour. The titration end-point was $\mathrm{pH} 7$. Hypersecretion was defined arbitrarily as a P.A.O. greater than $50 \mathrm{mmol} / \mathrm{h}$ in men and $40 \mathrm{mmol} / \mathrm{h}$ in women: firstly, because few normal people are found in our laboratory to secrete more acid than this; and, secondly, because of Kronborg's findings (1974). He found recurrent ulceration after truncal vagotomy and drainage in $21 \%$ of men whose preoperative P.A.O. was greater than $46 \mathrm{mmol} / \mathrm{h}$ and in $28 \%$ of women whose P.A.O. was greater than 42 $\mathrm{mmol} / \mathrm{h}$ before operation. According to our criteria 40 patients were hypersecretors. The clinical results in these patients were compared with those in 60 patients who had "normal" acid secretion, which was defined as a P.A.O. of $30-50 \mathrm{mmol} / \mathrm{h}$ in men and $25-40 \mathrm{mmol} / \mathrm{h}$ in women. We had intended to include a third group of "hyposecretors" with P.A.O. less than $30 \mathrm{mmol} / \mathrm{h}$ in men and $25 \mathrm{mmol} / \mathrm{h}$ in women, but the numbers were so small that analysis of the clinical results seemed pointless.
\end{abstract}

\section{TESTS OF ACID SECRETION}

Pentagastrin Test.-The dose of pentagastrin was $6 \mu \mathrm{g} / \mathrm{kg}$ body weight intramuscularly before operation and $10 \mu \mathrm{g} / \mathrm{kg}$ intramuscularly after H.S.V. (Johnston and Jepson, 1967; Johnston et al., 1973 a).

Insulin Test.-Basal acid output was collected for one hour. Soluble insulin $2 \mathrm{U} / \mathrm{kg}$ was then injected intravenously and acid output collected for a further two hours (Johnston et al., $1973 \mathrm{~b}$ ). Blood-glucose determinations, on venous blood samples collected 30 and 45 minutes after the injection of insulin, confirmed that glucose 
concentration decreased to less than $2 \cdot 2 \mathrm{mmol} / 1(40 \mathrm{mg} / 100 \mathrm{ml})$ in each test. The acid response to insulin was judged to be negative, early positive (in first hour), or late positive (in second hour), according to the criteria of Hollander (1948) and the modified Ross and Kay (1964) criteria.

\section{Results}

The two groups of patients are compared in table I. The mean reduction in P.A.O. after H.S.V. was similar in both groups, and the incidence of incomplete vagotomy, as assessed by the insulin test, was $7 \%$ in each group.

Clinical Results (Visick Grades).-The overall clinical results were similar in both groups. Altogether $82-93 \%$ of patients achieved very good (grade 2) or excellent (grade 1) clinical results at the different time intervals after operation. The incidence of clinical failure (grade 4) was similar in both groups: $3-9 \%$ in the hypersecretors and $5-9 \%$ in the normal secretors. No correlation was found between clinical failure and incompleteness of vagotomy or reduction in maximal acid output.

Pain.-The incidence of pain of ulcer type was $6 \%$ in each group. Several patients said that the pain was much milder than that which they had experienced before operation and it often lasted only a week or two. No patient who complained of pain had a positive insulin test result soon after operation, and the mean reduction in P.A.O. (45\%) in the patients with pain was only slightly less than the mean reduction in the whole group (49\%).

Recurrent Ulceration.-Patients who experienced persistent pain were fully investigated for recurrent ulceration. Laparotomy for suspected recurrence was carried out in two patients early in the series, but since 1970 patients suspected of having recurrent ulceration have undergone duodenoscopy, usually at least twice. In no case was a recurrent ulcer shown. After the operation none of the 100 patients suffered either perforation of their ulcer or significant gastrointestinal haemorrhage. Six patients in all were seriously suspected of having developed recurrent ulceration, and only two of them were hypersecretors.

Individual Symptoms. - The incidence of symptoms such as vomiting, heartburn, and diarrhoea is shown in table II. No statistically significant differences were found between the hypersecretors and the normal secretors. Early dumping, however, was recorded in only $1 \%$ of hypersecretors compared with $6 \%$ of normal secretors - an almost significant difference $(\mathbf{P}=0.054)$. Many symptoms were mild and transient. Epigastric fullness after meals, however, was a common symptom, which caused about $25 \%$ of patients in each group to restrict the size of their main meal of the day.

\section{Discussion}

Clearly, when H.S.V. is used as the standard operation for duodenal ulcer patients who have very high levels of acid secretion before operation fare as well clinically as those with lower acid outputs. Thus the addition of antrectomy in patients with hypersecretion of acid seems unnecessary. For the patient this is most pleasing because the operative mortality of vagotomy-antrectomy $(1.2 \%$; Cox et al., 1969; Herrington, 1969) is about four times that of H.S.V. (0.3\% ; our unpublished review of 5000 cases). Furthermore, vagotomy-antrectomy almost certainly produces more side effects and greater loss of weight than H.S.V. (Cox, 1968; Goligher et al., 1968; Humphrey et al., 1972; Johnston et al., 1972; Amdrup et al., 1974; Jordan, 1974 a ; Kronborg and Madsen, 1975).

Admittedly, follow-up of the patients after H.S.V. was relatively short, but recurrent ulceration after both vagotomy with drainage and H.S.V. is characteristically early, often occurring within two years after operation (Fawcett et al., 1969; Wastell et al., 1972; Small, 1973; Jordan, 1974 a ; Kronborg and Madsen, 1975). Since we have seen only two definite recurrences after H.S.V. in 300 patients treated over six years we believe that in the long term the incidence of recurrent ulceration in this series of patients will be low. If H.S.V. were an inadequate procedure for healing duodenal ulceration in hypersecretors we would probably have found many recurrences by now.

A low incidence of recurrent ulceration after H.S.V. (or "parietal cell vagotomy") in large series of patients has been reported from other centres (Grassi et al., 1973; Liavag and Roland, 1973; Moberg and Hedenstedt, 1973; Amdrup et al.,

TABLE I-Comparison of Two Groups of Patients. Results are Arithmetic Means $\pm 1 S$. E. of Mean

\begin{tabular}{|c|c|c|c|c|c|c|c|c|}
\hline & \multirow[b]{2}{*}{$\begin{array}{c}\text { No. } \\
\text { of } \\
\text { Patients }\end{array}$} & \multirow[b]{2}{*}{ Sex } & \multirow[b]{2}{*}{$\begin{array}{l}\text { Age Before } \\
\text { Operation } \\
\text { (years) }\end{array}$} & \multirow[b]{2}{*}{$\begin{array}{l}\text { Weight Before } \\
\text { Operation } \\
\text { (kg) }\end{array}$} & \multicolumn{3}{|c|}{ Peak Acid Output } & \multirow{2}{*}{$\begin{array}{c}\% \text { Positive* } \\
\text { on Insulin Test } \\
1 \text { Week After } \\
\text { Operation }\end{array}$} \\
\hline & & & & & $\begin{array}{c}\text { P.A.O. } \\
\text { Before } \\
\text { Operation } \\
(\mathrm{mmol} / \mathrm{h})\end{array}$ & $\begin{array}{l}\text { P.A.O. } \\
1 \text { week After } \\
\text { Operation } \\
(\mathrm{mmol} / \mathrm{h})\end{array}$ & Reduction & \\
\hline $\begin{array}{l}\text { High secretors } \\
\text { Normal secretors }\end{array}$ & $\begin{array}{l}40 \\
60\end{array}$ & $\begin{array}{l}34 \text { M. } 6 \mathrm{~F} \text {. } \\
47 \text { M. } 13 \mathrm{~F} \text {. }\end{array}$ & $\begin{array}{l}41.6 \pm 1.6 \\
41.9 \pm 1.6\end{array}$ & $\begin{array}{l}69 \cdot 4 \pm 1 \cdot 6 \\
62 \cdot 6 \pm 1 \cdot 3\end{array}$ & $\begin{array}{l}56 \cdot 8 \pm 1 \cdot 4 \\
38 \cdot 6 \pm 0 \cdot 8\end{array}$ & $\begin{array}{l}27 \cdot 4 \pm 1 \cdot 3 \\
20 \cdot 5 \pm 1 \cdot 2\end{array}$ & $\begin{array}{l}52 \cdot 1 \pm 2 \cdot 3 \\
47 \cdot 6 \pm 2 \cdot 8\end{array}$ & $\begin{array}{l}7 \\
7\end{array}$ \\
\hline
\end{tabular}

*By Hollander's (1948) criteria : two insulin results in high secretors were early postive (1st hour); remainder were late positive.

Conversion: SI to Traditional Units. $1 \mathrm{mmol} / \mathrm{h}=1 \mathrm{mEq} / \mathrm{h}$.

TABLE II-Incidence (\%) of Side Effects in Two Groups of Patients after Highly Selective Vagotomy

\begin{tabular}{|c|c|c|c|c|c|c|c|c|}
\hline & \multicolumn{2}{|c|}{ Year 1} & \multicolumn{2}{|c|}{ Year 2} & \multicolumn{2}{|c|}{ Year 3} & \multicolumn{2}{|c|}{ Year 4} \\
\hline & $\underset{\text { Secretors }}{\text { High }}$ & $\begin{array}{l}\text { Normal } \\
\text { Secretors }\end{array}$ & $\begin{array}{c}\text { High } \\
\text { Secretors }\end{array}$ & $\begin{array}{l}\text { Normal } \\
\text { Secretors }\end{array}$ & $\begin{array}{l}\text { High } \\
\text { Secretors }\end{array}$ & $\begin{array}{l}\text { Normal } \\
\text { Secretors }\end{array}$ & $\underset{\text { Secretors }}{\text { High }}$ & $\begin{array}{l}\text { Normal } \\
\text { Secretors }\end{array}$ \\
\hline $\begin{array}{l}\text { No. of patients* } \\
\text { Size of Meals: } \\
\text { Normal } \\
\frac{2}{3-\frac{3}{4} \text { of Normal }} \\
<\frac{2}{3} \text { of Normal }\end{array}$ & $\begin{array}{r}39 \\
75 \\
19 \\
6\end{array}$ & $\begin{array}{r}55 \\
73 \\
22 \\
5\end{array}$ & $\begin{array}{l}37 \\
73 \\
16 \\
11\end{array}$ & $\begin{array}{r}53 \\
80 \\
12 \\
8\end{array}$ & $\begin{array}{r}23 \\
82 \\
9 \\
9\end{array}$ & $\begin{array}{r}38 \\
76 \\
24 \\
0\end{array}$ & $\begin{array}{r}12 \\
75 \\
17 \\
8\end{array}$ & $\begin{array}{l}21 \\
71 \\
19 \\
10\end{array}$ \\
\hline $\begin{array}{l}\text { Diarrhoea } \\
\text { Nausea } \\
\text { Vomiting: }\end{array}$ & $\begin{array}{r}8 \\
10\end{array}$ & $\begin{array}{r}0 \\
15\end{array}$ & $\begin{array}{l}5 \\
8\end{array}$ & $\begin{array}{r}4 \\
11\end{array}$ & $\begin{array}{l}5 \\
4\end{array}$ & $\begin{array}{l}3 \\
0\end{array}$ & $\begin{array}{r}0 \\
17\end{array}$ & $\begin{array}{l}5 \\
5\end{array}$ \\
\hline $\begin{array}{l}\text { Bile } \\
\text { Food } \\
\text { Epigastric fullness }\end{array}$ & $\begin{array}{r}3 \\
5 \\
26\end{array}$ & $\begin{array}{r}2 \\
8 \\
32\end{array}$ & $\begin{array}{r}3 \\
0 \\
30\end{array}$ & $\begin{array}{r}0 \\
4 \\
26\end{array}$ & $\begin{array}{r}9 \\
0 \\
17\end{array}$ & $\begin{array}{r}0 \\
0 \\
24\end{array}$ & $\begin{array}{r}8 \\
0 \\
17\end{array}$ & $\begin{array}{r}0 \\
5 \\
24\end{array}$ \\
\hline $\begin{array}{l}\text { Dumping: } \\
\text { Early } \\
\text { Late } \\
\text { Flatulence } \\
\text { Heartburn or reflux } \\
\text { Dysphagia }\end{array}$ & $\begin{array}{r}0 \\
0 \\
13 \\
5 \\
0\end{array}$ & $\begin{array}{r}6 \\
0 \\
27 \\
13 \\
0\end{array}$ & $\begin{array}{r}0 \\
0 \\
22 \\
19 \\
0\end{array}$ & $\begin{array}{r}4 \\
2 \\
19 \\
17 \\
0\end{array}$ & $\begin{array}{r}0 \\
5 \\
26 \\
17 \\
0\end{array}$ & $\begin{array}{r}5 \\
5 \\
18 \\
21 \\
0\end{array}$ & $\begin{array}{r}8 \\
17 \\
33 \\
33 \\
0\end{array}$ & $\begin{array}{r}10 \\
5 \\
10 \\
19 \\
0\end{array}$ \\
\hline
\end{tabular}

*Some patients failed to attend for review each year. It should be noted that side effects were usually mild and intermittent. 
1974; Jordan 1974 b). Wastell et al. (1972) however, reported two cases of recurrent ulcer within a few months of H.S.V. in a small series, and 22\% of Kronborg and Madsen's (1975) 50 patients developed recurrent ulceration within four years of H.S.V. The early postoperative insulin test, however, showed that $58 \%$ of Kronborg and Madsen's patients and $28 \%$ of those of Wastell et al., had incomplete vagotomy. Since there is a good correlation between insulin positivity soon after vagotomy and subsequent recurrent ulceration (Bell et al., 1965; Johnston et al., 1967; Baron, 1973; Kennedy et al., 1973) it is perhaps not surprising that the incidence of recurrent ulceration after H.S.V. in these series was high.

Hence our conclusion-that the addition of antrectomy to vagotomy is unnecessary when patients with hypersecretion of acid are treated by H.S.V.- -is valid only if the H.S.V. is shown to be complete either at the time of operation or on insulin testing soon after operation. In view of the greater risk to life and the long-term disadvantages of antrectomy we think it best to avoid antrectomy but to spare no effect to ensure that the vagotomy of the parietal cell mass is complete at operation. Using operative techniques described previously (Johnston and Wilkinson, 1970; Goligher, 1974) we kept the incidence of incomplete vagotomy at $7 \%$. The ability of junior members of staff, who now perform many of the H.S.V. operations, to achieve a complete vagotomy differs little from that of the consultants. Hence the technical aspects of this operation are well within the capability of any surgeon who is prepared to study the technique and begin using H.S.V. cautiously in slim patients.

It is important that the completeness of the parietal cell vagotomy should be monitored. Such a "quality control" is provided after operation by the insulin test. If this test gives positive results in no more than $10-15 \%$ of patients probably nothing more need be done because the incidence of recurrent ulceration should be low. If the incidence of incomplete vagotomy is higher, however, the operative technique should be reassessed and consideration given to the use of some intraoperative test. Such tests have not secured wide acceptance, but they are unquestionably a more rational form of quality control than the insulin test, because if the vagotomy is incomplete a determined effort can be made to complete it, and the outcome of the surgeon's endeavours can be assessed once more. Such intraoperative tests are the Burge test (Burge and Vane, 1958; Burge and Frohn, 1969) and the Grassi test (Grassi, 1971). It is better to use these tests than to subject a significant proportion of patients to an unnecessary and potentially harmful antrectomy.

We thank Mr. A. R. Wilkinson, Mr. C. S. Humphrey, Mr. R. B. Smith, and Dr. P. J. Lyndon, who performed the tests of acid secretion. I. R. Pickford was spending an elective studentship in the university department of surgery.

\section{References}

Amdrup, E. et al. (1974). Annals of Surgery, 180, 279.

Baron, J. H. (1973). In Vagotomy on Trial, ed. A. G. Cox and J. AlexanderWilliams, p. 7. London, Heinemann.

Bell, P. R. F. et al. (1965). Lancet, 2, 978.

Bruce, J.et al. (1959). Fournal of the Royal College of Surgeons of Edinburgh, 4,85 .

Burge, H., and Vane, J. R. (1958). British Medical fournal, 1, 615.

Burge, H., and Frohn, M. J. N. (1969). British Fournal of Surgery, 56, 452. Cox, A. G., (1968). British Medical fournal, 1, 288.

Cox, A. G., Spencer, J., and Tinker, J. (1969). In After Vagotomy, ed. J. A. Williams and A. G. Cox, p. 120. London, Butterworths.

Fawcett, A.N., Johnston, D, and Duthie, H.L. (1969). British fournal of Surgery, 56, 111.

Goligher, J. C.e et al., (1968). British Medical fournal, 2, 781.

Grassi, G. (1971). British fournal of Surgery, 58, 187.

Grassi, G. et al. (1973). Surgery, Gynecology and Obstetrics, 136, 726.

Herrington, J. L., jun. (1969). In Surgery of the Stomach and Duodenum, ed. H. N. Harkins and L. M. Nyhus, 2nd edn., p. 575. Boston, Little,
Brown and Co.

Hollander, F. (1948). Gastroenterology, 11, 419.

Humphrey, C. S. et al. (1972). British Medical fournal, 3, 785.

Johnston, D. et al. (1967). British fournal of Surgery, 54, 831.

Johnston, D., and Jepson, K. (1967). Lancet, 2, 585 .

Johnston, D. et al. (1972). British Medical fournal, 3, 788.

Johnston, D. et al. (1972). British Medical fournal, 3,

Johnston, D. et al. (1973 a). Gastroenterology, 64, 1.

Johnston, D., and Wilkinson, A. R. (1969). British fournal of Surgery, 56, 626.

Johnston, D., and Wilkinson, A. R. (1970). British fournal of Surgery, 57, 289.

Jordan, P. H. Jun. (1974 a). Annals of Surgery, 180, 259.

Jordan, P. H. Jun. (1974 b). Archives of Surgery, 108, 434.

Kennedy, F. et al. (1973). British Medical fournal, 2, 71.

Kronborg, O. (1972). Scandinavian fournal of Gastroenterology, 7, 423.

Kronborg, O. (1974). Gut, 15, 714.

Kronborg, O., and Madsen, P. (1975). Gut. In Press.

Liavag, I., and Roland, M. (1973). Scandinavian fournal of Gastroenterology, 8, Suppl. 20, p. 10.

Moberg, S., and Hedenstedt, S. (1973). Scandinavian fournal of Gastroenterology, 8, Suppl. 20, p. 9 .

Robbs, J. V.et al. (1973). British fournal of Surgery, 60, 601.

Ross, B., and Kay, A. W. (1964). Gastroenterology, 46, 379.

Small, W. P. et al. (1967). British fournal of Surgery, 54, 838.

Small, W. P. (1973). Clinics in Gastroenterology, 2, 427.

Smithwick, R. H., Harrower, H. W., and Farmer, D. A. (1961). American fournal of Surgery, 101, 325.

Wastell, C. et al. (1972). British Medical fournal, 1, 28.

\title{
Depression of Sublingual Temperature by Cold Saliva
}

\author{
R. E. G. SLOAN, W. R. KEATINGE
}

British Medical fournal, 1975, 1, 718-720

\begin{abstract}
Summary
Sublingual and oesophageal temperatures were compared at various air temperatures in 16 subjects. In warm air $\left(25-44^{\circ} \mathrm{C}\right)$ sublingual temperatures stabilized within $\pm 0.45^{\circ} \mathrm{C}$ of oesophageal temperatures, but in air at room temperature $\left(18-24^{\circ} \mathrm{C}\right)$ they were sometimes as much as $1 \cdot 1^{\circ} \mathrm{C}$ below and in cold air $\left(5-10^{\circ} \mathrm{C}\right)$ as much as $4 \cdot 4^{\circ} \mathrm{C}$ below oesophageal readings. The sublingualoesophageal temperature difference in cold air was
\end{abstract}

\footnotetext{
Department of Physiology, London Hospital Medical College, London E1 2AD

R. E. G. SLOAN, M.B., B.sc., Lecturer in Physiology

W. R. KEATINGE, M.B., PH.D., Professor of Physiology
}

greatly reduced by keeping the face warm, but it was not reduced in two patients breathing through tracheostomies and thereby eliminating cold air flow from the nose and pharynx. Parotid saliva temperature was low and saliva flow high during exposure, and cold saliva seemed to be mainly responsible for the erratic depression of sublingual temperature in the cold. These results indicate hazards in the casual use of sublingual temperatures, and indicate that external heat may have to be supplied to enable them to give reliable clinical assessments of body temperature.

\section{Introduction}

The sublingual reading normally used for routine clinical measurement of body temperature is depressed in cold air and therefore unsuitable for assessing hypothermia (Pembrey, 1898; Fox et al., 1971), though it is generally considered reliable in air 